\title{
State and Industrial Policy: Comparative Political Economic Analysis of Automotive Industrial Policies in Malaysia and Thailand
}

\author{
Wan-Ping Tai \\ Samuel C. Y. Ku
}

\author{
Cheng Shiu University, Taiwan \\ National Sun Yat-Sen University, Taiwan
}

\begin{abstract}
Numerous differences exist between the neoclassical and national development schools of economics on how an economy should develop. For example, should the state interfere in the market using state resources, and cultivate certain industries to achieve specific developmental goals? Although the automotive industries in both Thailand and Malaysia developed in the 1970s with considerable government involvement, they have evolved along very different lines. Can these differences be traced to different interactions between the state and industry in these two countries? This paper examines this issue and finds that although industries in developing countries need government assistance, the specific political and economic contexts of each country affect the policies adopted and their effectiveness. The choice between "autonomous development" (Malaysia) and "dependent development" (Thailand) is the first issue. The second issue is that politics in Malaysia has deterred the automotive industry from adopting a "market following" position. This paper finds that the choice of strategy and political interference are the two main reasons the automotive industry in Malaysia is less competitive than that in Thailand.
\end{abstract}

Keywords: Automotive Industry, Developmental State, Malaysia Automotive Industry, Thai Automotive Industry, PROTON, Political Economic Analysis

\section{Introduction}

In the wake of the 2008 economic crash, whether the U.S. government should financially support the domestic automotive industry has become a matter of debate. The automotive industry has been one of the three main industries in the U.S. for the past hundred years, and is involved in other sectors and industries as diverse as iron, oil, manufacturing, sales, the stock market, credit, and insurance. Because of the huge knock-on effects that a collapse of this industry might have on the wider economy, the possibility of government intervention in the U.S. automotive industry remains an option (Yun-Han Chu, 2008: 20). 
This debate has touched on issues related to developmental economics such as, when a new industry is launched or faces crises, should the state intervene and help the industry, or should they follow the selective policy to help only certain firms? In what type of situation should governments intervene? Will state resources devoted to the industry be used efficiently to reach the development goal? These topics have been the focus of debates that have never reached a consensus.

Most scholars of developmental economics feel that because of lacking market mechanisms and limited resources in developing nations, policy intervention in industry is necessary to accelerate industrialization. However, although industries in developing countries need state intervention, not all such interventions yield expected results. Could such supported industries survive when the government withdraws its protection? What are the costs and benefits for the government under these policy interventions? How can international pressure to remove such protection be handled? To protect vested interests, manufacturers might use non-financial resources to raise barriers to entry, thus weakening their own market competitiveness, which lead to poor results in the long term. All of these issues are important for studies of economic policies adopted in developing countries (Wan-Wen Chu, 2001: 67).

Differing from the diverse studies of East Asian countries such as Taiwan, Japan, and South Korea, on official organization and industry development, relevant issues between the state and industrial policies in Southeast Asian countries are seldom focused. This study discusses the policies for the automotive industry in Malaysia and Thailand because both of these developing countries have been eager to upgrade their domestic industrial base by developing the car sector (Rasiah, 1999). However, despite sharing a number of similarities in their developmental backgrounds and with governmental organizations taking a leading role in the industry, they have also diverged and chosen relatively different paths to further development. Malaysia has adopted its automotive industry as a national industry, with an "independent development" strategy applied to establish a national brand, whereas Thailand has chosen to cooperate with international car manufacturers and adopted the "dependent development" strategy, which has made its domestic automotive industry part of the worldwide supply chain. The results of these two strategies show that the "independent development" of Malaysia has yielded fewer benefits (Fuangkajonsak, 2006: 1-3).

Examining the development of the automotive industry with the development of politics and economics in countries can obtain a clearer picture of the relationship between the state and industrial development. This article does not focus on the theoretical study of specific issues related to developing countries, but analyzes how different historical systems result in different strategic choices and developmental effects by integrating international and domestic political and economic factors ( Abbott, 2003). Although industrial development in developing countries relies on government intervention, the economic and political background of each country affects their selection of specific strategies: namely, the strategic choice between the "independent development" of Malaysia and the "dependent development" of Thailand; then the "politicality" of the automotive industry in Malaysia intervened with the "follow-the-market" policy. The results of "strategic selection" and "political intervention" are the two main reasons this article concludes that the development of 
the automotive industry in Malaysia has been inferior to that in Thailand.

\section{Theoretical Study: The state, industrial development, and automotive industry policies.}

\section{The State and Industrial Development}

Scholars typically discuss the developmental patterns of a national industry from two perspectives. Under a good economic environment, scholars following neo-classical economics believe that industry grows spontaneously with a comparative advantage. In their view, competition should be free and open at the start of an industry to allow private investors to allot resources based on economic rationality because this is best able to raise competitiveness (Balassa, 1988: 27-57; Bhagwati, 1988: 27-57). Scholars of liberalism accept this view (Kruegert, 1993). The East Asian Miracle: Economic Growth and Public Policy, published in 1993 by the World Bank, is a typical work from this school (Stiglitz and Shahid, 1994). Its main conclusion was that giving up market price control is essential when hoping to develop industrial competitiveness in transforming agriculture in developing countries.

However, scholars from the school of development economics have raised numerous doubts of the neoclassical approach (Fishlow, 1994; Lindauder, 1994: 12). Some make a case for the so-called "Dependency Theory," which proposes that international factors, particularly the political and economic power from hegemonic countries, such as the United States, play an active economic role in developing countries. This type of development is known as "invited development." Other scholars state that economic progress is not mainly caused by "market" and "internationality." They do not believe that economic development in developing countries, particularly East Asian countries, should ascribe to governments remaining neutral, and they also criticize the World Bank report for neglecting the importance of the state in industrial development.

These scholars offer an extremely different explanation from neoclassical economics (Jomo, 1994): 461-508). For example, Johnson introduced a concept of "developing-type country" for Japanese industrial research in 1982, which stated that industrialization in the so-called New Nations is related to the great promotion of economic development by the state (Johnson, 1982; Shumpei Kumon and Henry Rosovsky, 1972: 109-141). Taking South Korea as an example, Hasan claimed that its successful economy was based on government intervention. Hasan also stated, "The economy in South Korea relies on the operation of private enterprises that are in fact directed by the central government. The state not only establishes policies and rules, but also dominates the economy by controlling market mechanisms, and thus has a critical impact on all entrepreneurial decisions (Hasan, 1976).

Those scholars who support "Developmental State Theory" think that industrial development in developing countries relies on intervention and protection from the state. This authorizes the government to control the production, allotment, and price of goods to reach the best arrangement of resources (Kuckiki, 2007: 3-6). They believe that despite liberalism aiding industrialization, the lack of a market mechanism might lead to an environment that increases the risk to industry and adversely influence production. With insufficient private investment and limited resources, selective government intervention becomes necessary for rapid industrialization (WanWen Chu, 1997: 99-100). These ideas highlight the following two phenomena for 
the relationship between the state and industrial policies:

1. The state provides necessary production factors: To facilitate economic development, the government commands the financial system to finance industries for upgrading or expansion. These funds are typically preferential loans with interest rates that are substantially lower than the market rate, and are helpful for industrial growth.

2. The state launches policy intervention to protect industries: At the initial stages of development, industries are typically unable to compete with foreign firms; therefore, to encourage industrial development and expand export trade, the state provides support with preferential tax policies and work to limit competition (Freeman, 1982: 90-112).

\section{Industrial policy and automotive industry policy}

Automotive industry has been an important issue for scholars involved in research on "the State" and "industrial policy" in developing countries (Jenkins, 1987; Jenkins, 1995: 625-645; Doner, 1991). Many developing countries, such as Brazil, Mexico, South Korea, and previously Taiwan, have attempted to make the automotive industry the motivator of industrialization. However, for some countries (such as Taiwan), such intervention has proved unsuccessful in the car industry and needs further research (Jenkins, 1995: 642). The application of automotive industry technology often expands to other industries, thus contributing greatly to the national economy by promoting technological abilities, increasing employment opportunities, and revenue (Dicken, 1998:
316; Humphrey, 2000: 245-271). The automotive industry belongs to a high value-added industry, which is also a capital-intensive and technology-intensive industry. The production process involves upstream industries such as steel, electronics, and plastic industries, and has great influence on downstream industries such as marketing, service, maintenance, insurance, and finance industries (Konosuke, 1993). Therefore, based on the goal of industrial development and political and economic backgrounds, many countries employ various policies, such as "Limited local content rate," "Energy consumption standards," "Limited auto import tax," "Limited import quantity," "Import quotas," and "Import Substituting Industrialization Strategy," to fulfill the purpose of policy intervention in the auto industry Rasiah, 1997). Scholars normally divide automotive industry development into four stages:

1. Importing Completely Built up vehicles (hereafter referred to as CBU)

2. Semi-Knocked Down (SKD) and Completely Knocked-Down (hereafter referred to as CKD)

3. Full Assembly

4. Manufacturing

National intervention has three goals in these stages (Fitzgerald eds, 1995): First, to establish the industrial scale. The state normally assists local enterprises to establish an industrial supply chain to promote local production of key components through an "import substitution" policy. Second, to help the automotive industry transform through the "assembly," "semi-assembly," "fully assembled," to "manufacturing" stages, which requires that the rate of locally made parts must reach certain percentages. Third, the state becomes the driver of industrial 
internationalization. When the local automotive industry has the capacity to manufacture a whole car, the state can help them export products to other countries through consolidation, production control, and a unified development model. The final goal is for local firms to be able to set up production plants in other countries and form transnational automotive groups.

During the transformation process from "assembly" to "manufacturing," the state normally has two choices, "dependency development" and "independent development". First, the dependency development mode is a way to increase industrial competitiveness that relies on foreign technology and fund of funds. Therefore, it is necessary to open domestic markets to attract foreign investment-led industrial development. This typically means that after Transnational Automotive Corporations (TNCs) obtain a license, they set up local assembly plants and help domestic enterprises establish an industrial scale of component manufacturing. For example, local firms in Mexico, Brazil, and Spain were all aided by multinational corporations and thus able to develop highly efficient supply chains to then build an internationalized automotive industry with some areas of comparative advantage (such as market, location, and labor force).

Second, the independent development mode is a policy that can raise competitiveness of the local automotive industry by relying on the development of a monopolistic market, with the supply chain formed by local investors and enterprises. For example, South Korea relied on its own strength to develop an automotive industry, gradually building up R\&D capabilities and a local brand. ${ }^{1}$

\footnotetext{
1 Taking South Korea as an example, the Automotive Industry Promotion Law was passed in 1962. Auto imports were prohibited and large-scale enterprises were chosen as the main participants of the automotive industry. South Korea thus became the
}

These two approaches have both advantages and disadvantages (See Table $1)$.

Based on this discussion, this research makes the following analysis: Because of the lack of market mechanisms and limited resources, to accelerate industrialization, developing countries rely on state intervention as a protection measure; therefore, selective intervention is necessary. Furthermore, the automotive industry plays a major role in promoting industrialization in developing countries. National intervention has the following three targets: first, to establish the foundation of the industry; second, transform the industry from "component assembly" to "manufacturing;" third, the state becomes the driver of industrial internationalization. Moreover, industrial interventions do not necessarily reach the goal of nurturing the automotive industry. Considering whether the industry could be self-reliant after receiving protection, and if the benefits outweigh the social costs produced in the protectionist period, is necessary In addition, how will a protected industry eventually adapt to a more open international market?

world's key auto production base and the fourth largest auto production country in a short period. 

Table 1: Analysis of Different Automotive industry Development Approaches

\begin{tabular}{|c|c|c|}
\hline Approach & Advantages & Disadvantages \\
\hline $\begin{array}{l}\text { Dependency } \\
\text { development }\end{array}$ & $\begin{array}{l}\text { - Smaller financial } \\
\text { burden on the } \\
\text { government } \\
\text { - Less pressure on the } \\
\text { open market }\end{array}$ & $\begin{array}{l}\text { - The automotive industry is } \\
\text { dominated by foreign capital } \\
\text { - More difficult to develop the } \\
\text { economic scale of mass } \\
\text { production } \\
\text { - Cannot bring about the growth } \\
\text { of related industries }\end{array}$ \\
\hline $\begin{array}{l}\text { Independent } \\
\text { development }\end{array}$ & $\begin{array}{l}\text { - Protection brings mass } \\
\text { production } \\
\text { - More likely to support } \\
\text { the growth of related } \\
\text { industries } \\
\text { - Can use the home } \\
\text { country's resources }\end{array}$ & $\begin{array}{l}\text { - Greater financial burden on the } \\
\text { government } \\
\text { - Over-protection cannot respond } \\
\text { to pressure from trade } \\
\text { liberalization }\end{array}$ \\
\hline
\end{tabular}

Source: Organized and rewritten by the author, based on Rashid, 2006.

\section{Establishment of Malaysia's automotive industry}

\section{Establishment of the automotive industry}

Malaysia's automotive industry was established in 1963. Under the Colombo Plan, the Malaysian government formulated a localized production policy for the automotive industry. In 1964, the Malaysian government set out a policy of promoting vehicle assembly and localized component production, and thus prohibited the import of completely built vehicles and implemented localized production. The Ministry of Trade and Industry founded the Motor Vehicle Assemblers Committee (MVAC), responsible for reviews of related investment. Consequently, companies engaged in the import of $\mathrm{CBU}$ had to manage complex import processes and pay high import taxes, and thus the import of assembly cars grew very rapidly (Torii, 1991). Certain restrictions were employed, such as an import duty on CBU or control of the auto dealer by license renewal twice a year.
In 1967, the Malaysian government approved the establishment of six auto assembly plants. In the same year, it passed the Investment Incentive Act to encourage more assembly cars to use locally made auto parts. At this early stage, assembly plants were established by joint ventures between European manufacturers and local enterprises, and the assembled vehicles were mainly European and Japanese cars, with the latter coming to dominate the Malaysian car-assembly market in the 1970s.

Although Malaysia hoped to promote the growth of the local component production industry by increasing the level of local manufacturing, because of numerous assembly manufacturers and different vehicles needing various components, it was impossible to conduct mass production, and thus the products produced did not have any price advantage. To elevate the quality of locally made components, the Malaysian government proposed the Mandatory Deletion Program in 1979, to weed out unqualified manufacturers, simplify production, and 
increase industrial competitiveness. However, the Japanese-based group of foreign car manufacturers and ChineseMalaysian investors still controlled automotive assembly, component production, and marketing. Therefore, the Malaysian government began to consider transforming its assembly-oriented industry into a car manufacturing one.

Homemade vehicle plans and internationalization of the automotive industry

The transformation of Malaysia's automotive industry began in 1982, when Prime Minister Mahathir announced the homemade vehicle production plan, which was controlled by The Heavy Industries Corporation of Malaysia Berhad (HICOM), the group responsible for implementing the country's National Heavy Industries Plan and Industrial Master Plan Project (IMP). These actions were taken in hopes of leading the automotive industry into the self-development mode.

To reach this goal, HICOM chose to cooperate with Japan's Mitsubishi Motors to establish PROTON Motors (perusahaan otomotif). HICOM held $70 \%$ of the shares in this company, and Mitsubishi Motors had the remaining $30 \%$. At first, PROTON was only responsible for vehicle assembly, but with government support, it gradually began to take charge of design, mechanics, logistics, and marketing. In 1985, PROTON SAGA launched its own brand car, SAGA. In the mid-80s, Malaysia underwent an economic crisis caused by the oil market collapse, existing markets re-shuffled, and PROTON became the leading brand in the Malaysia auto market (Wad, 1999).

\section{The state of Malaysia and Automotive industry}

The form of the state, its structure, and developmental strategy have an obvious connection to its interaction with civil society. In the social structure of Malaysia, conflicts among ethnic groups are closely related to industrial policy (Soong, 1996). In 1969, because of economic inequality, the so-called "513 race riots" broke out and became an important turning point in the economic development of Malaysia. $^{2}$ Afterwards, the Malaysian government proposed its New Economic Policy (NEP) in 1971, developed a technocrat bureaucrat authoritarian regime, and directly intervened in economic development through the "Kuota" (quota) system to reduce economic inequality between ethnic groups.

The new economic policy was based on the concept of "National Capitalism," and tried to raise the proportion of the indigenous Malay Group" (or Bumiputra), an ethnic group that participated in the economy, ${ }^{3}$ thus promoting the ethnic redistribution of wealth, and relieving conflict. The development mode of national capitalism in Malaysia in this period was state-driven, with the government directly intervening in the market (Soong, 1996).

The state during this period primarily focused on the automotive industry and considered it the national industry of

\footnotetext{
2 Malaysia's three main ethnic groups are Malays, Chinese, and Indians, and the respective proportions are approximately $62 \%, 30 \%$, and $8 \%$. Most scholars think "Racial communitarianism" is the main characteristics of Malaysia. See Samuel C.Y. Ku, Government and Politics in Southeast Asia, (Taipei: Wunan, 1995), p.71. In the election of May, 1969, Malaysia's ruling coalition suffered defeat, which caused a series of racial conflicts, claimed 196 lives, and wounded 439. The Malay ruling elite believed the fundamental reason was long-term conflicts, unequal policy, mistrust, opposition, and ethnocentrism between Malay and Chinese. See B. T. Khoo, The Paradoxes of Mahathirism (New York: Oxford University Press, 1995), pp. 52-54.

3 Bumiputra originates from Sanskrit, which means sons of the soil. According to the constitution of Malaysia, it refers to the Malay community in Malaysia and the minority groups in Sabah and Sarawak.
} 
Malaysia. ${ }^{4}$ Malaysia's automotive industry development started with car assembly (1963-1982), and then Mahathir promoted the Homemade cars Plan in 1982 and encouraged the local automotive industry to work on exports. The aim of this plan was to improve the low domestic rate and alter the industrial structure, which was dominated by ethnic Chinese investors. In an attempt to lead private sector investment, the state of Malaysia used various strategic industrial policy tools, such as tax incentives and subsidies, preferential bank loans, market protection, government orders, and technology development to develop a strategic industrial policy (Camilleri, 2000).

To ensure smooth development of its domestic vehicle plan, the state of Malaysia instituted a series of industrial policy interventions, including the following actions (Gustafsson, 2006):

1. Increased import tariffs on completely built vehicles and components;

2. Implemented quotas for imported cars;

3. Encouraged foreign capital to participate in domestic car programs

4. Offered production subsidies to domestic auto parts manufacturers, lowered the price of components from $10 \%$ to $12 \%$, increased tariff on imported components, and prolonged items tax relief, so that the price of homemade vehicles would be lower than that of imported cars of the same standard

5. Encouraged domestic car manufacturers to export vehicles and auto parts (especial OEM parts) to ASEAN countries, and used the

\footnotetext{
4 Automotive Federation of Malaysia (AFM), "Submission of AFM on the Industrial Master Plan," in The ASEAN Motor Industry in Economist Intelligence Unit (KL: EIU, 1984), p. 1.
}

export channels of technical cooperation plants to sell them to other Asian countries.

6. Offered civil service low-interest loans to purchase domestic cars.

With the Homemade Cars Plan to build up the brand PROTON, Malaysia employed the independent development strategy in an attempt to build the industry through state protection, which was initially effective. In 1989, PROTON began to export vehicles to other countries. From the latter 1980s to the early 1990s, the domestic market share of PROTON SAGA models was nearly $45 \%$. PROTON merged with Lotus, a leading British brand, in 1997, and became the focus of the international automotive market. In addition to PROTON, the second domestic car, PERODUA, was also developed with state support in October 1992, with the aim to provide a large-scale supplier for the spare parts market. In its heyday, because of the automotive group formed by PROTON and PERODUA, the supply chain had 350 chain-related companies, with a total investment of RM 4.6 billion, employing more than three million people, and producing 6,000 auto parts, nearly RM 20 billion worth. PROTON has not only become the largest brand in the Malaysia car market, but also the only domestically manufactured car brand in an ASEAN country.

\section{Establishment of Thailand's automotive industry}

Contrasted to Malaysia, the industrial development of Thailand was led by foreign capital and the private sector, and the state did not participate as an active leader. In the case of the automotive industry, the Thai government mainly cooperated with multinational corporations (MNCs), offering various incentives to encourage them to build production bases in Thailand. 
Local enterprises produced spare parts and became peripheral industries.

The development of Thailand's automotive industry is divided into four stages: first, the establishment stage (19611970), focusing on creating production capacity; second, the national regulatory period (1971-1989), focusing on strengthening production and further localization; third, and fourth: liberalization (1990-now), focusing on full liberalization and export promotion, in response to the liberalization trend of world trade.

The establishment period (1960-1980): import substitution policy

The automotive industry in Thailand began in the 1960s, following the period in which all cars were imported. The first auto company, Thai Motor Industry Company, was established in 1961. The next year, The Office of the Board Investment was set up and offered many preferential terms for the automotive assembly industry. Industrial development can bring economic development; therefore, the state began to nurture the domestic automotive industry, hoping to cooperate with European and Japanese manufacturers to establish an industrial base. In this stage, the state of Thailand offered foreign investors the following preferential terms (Fujita, 1998):

1. Fifty percent reduction in import tariffs on completely knocked-down vehicles (CKD) for five years;

2. Five-year joint venture income tax relief;

3. Free remittance of foreign exchange;

4. Free flow of capital and technology in Thailand

After implementing these preferential terms for industrial development, the numbers of car assembly plants rapidly increased. In 1967, the state of Thailand established The Federation of Thai Industries, which took charge of integrating and planning Thailand's state-led industrial development. At that time, Thailand lacked industrial experience and local personnel who were good at management, and thus needed help from foreign investors and firms. Therefore, during the early days of the automotive industry, the state allowed multinational automotive groups to cooperate with local investors to form joint ventures.

Those assembly plants that were granted privileges from the state enjoyed lower tariffs for whole vehicle components. However, importing large quantities of components led to serious payment deficits in Thailand. This problem became more apparent in the late 1960s, and thus in 1969, the state ceased establishing auto manufacturing companies under the advice of the Parliament Automotive Industry Development Committee, reexamined the developmental direction of the industrial sector, and changed to nurturing the domestic industry by "import-substitution industrialization." To ensure industrial autonomy, the Ministry of Industry (MOI) announced a comprehensive reform program for the auto industry in 1971, which required that local assembly vehicles use at least $25 \%$ locally made components.

The policy of economic nationalism upheld by Prime Minister Thanom Kittikchorn was the main reason for this change. Thanom tried to implement national capitalism to revitalize industry, avoid economic exploitation of foreign capital, and achieve the modernization of Thailand. He believed the state should lead in the development of the automotive industry through working with domestic investors and The Federation of Thai Industries, and help local producers compete against imports through protectionist policies.

To strengthen the development of local industry and reach an enhanced economic scale of production, in the 1970s, the state of 
Thailand restricted the number of domestic assembly car models and further promoted localization, which aided the development of the component sector (Fujita, 1998). The Thai Auto-Parts Manufacturers Association (TAPMA) was established in 1978 and served as a mechanism for industrial integration and development of the component manufacturing industry. In the same year, the state of Thailand announced the prohibition of whole vehicle import (CBU) and increased tariffs on import assembly (CKD) as the first step to protect the domestic automotive industry. Under these measures, the state ceased granting production privileges and increased the required proportion of domestic production parts, gradually increasing the number of local component manufacturers.

\section{The relaxation period (1980-1989)}

Following the second oil crisis in 1979, the prices of agricultural products in Thailand fell and caused heavy economic losses. In the hope of obtaining loans from the World Bank, and facing pressure from multiple forces in society and multinational corporations, civil society groups, led by the Joint Public Private Consultative Committee (JPPCC, established in 1981), required a change in economic policies in Thailand from import substitution to export-oriented. This change had a significant influence on the development of the automotive industry (Abdulsomad, 2003). In 1982, Thailand froze the 1978 "Ratio of Origin" requirement. In addition to policy transformation, the state of Thailand also hoped that the automotive industry could develop a key competitive advantage, and thus focused on pick-up trucks as the main product, and worked to position the nation as the global production center for such vehicles.

To increase the use of local components, in 1984, the government announced a joint project between Peugeot France and local enterprises, known as the Domestic Car
Manufacturing Project (Kesavatana, 1989). The plan projected that $95 \%$ of Thai car components were to be locally produced. However, because this might have caused a significant loss of tariffs for imported components, several interest groups and government agencies opposed this plan, which ultimately suspended the domestic car project.

After 1985, Thailand's automotive industry underwent several significant changes. The "Plaza Accord" forced the appreciation of the yen, ${ }^{5}$ and Japanese enterprises needed to move overseas to lower-cost locations, causing Thailand to become the first overseas investment choice for the Japanese automotive industry. ${ }^{6}$ Taking this opportunity, the state of Thailand offered increasing tax concessions to Japanese-based multinational corporations, and created an environment that was more conducive for their investments. These industrial liberalization measures caused foreign investment (FDI) to rise. Increased foreign capital maintained Thailand's economic growth rate at $9 \%$ on average, causing the rise of a middle class, which increased demand in the domestic automotive market. The rising middle class and the development of a partially liberalized automotive industry forced the

\footnotetext{
5 September 22, 1985, United States, Japan, Britain, France, and West Germany, the five industrial countries, gathered at the Plaza Hotel, New York, for a secret meeting. Their finance ministers and central bank presidents signed the famous "Plaza Accord" to undertake joint intervention in the foreign exchange market, forcing the U.S. dollar down against the Japanese yen, German mark, and other major currencies in an orderly manner, to resolve the massive U.S. trade deficit, which led to significant appreciation of the Japanese yen.

${ }^{6}$ Thailand particularly welcomed Japanese capital, mainly because Japanese investment was laborintensive and could create more job opportunities. Moving the major market to a foreign country (i.e. reexports) could reduce the exploitation potential by the Japanese market.
} 
state to consider reopening the market for import cars.

\section{The export-oriented period (1990-2000)}

Under the ruling of reformist Prime Minister Anand Punyarachun, the state of Thailand gradually abolished the restrictions on the automotive industry in the 1990s by partially reopening the market for imported vehicles, and substantially lowering tariffs on imported cars and components. In 1993, the Thai government announced the Export Promotion Project of the Automotive industry, and abolished restrictions on setting up auto assembly plants by foreign firms, transformed the domestic market-oriented industrial policy to an export-oriented one, and boosted exports to deal with increasing import competition. These changes led the growth rate of automotive manufacturing to become the highest in the world from 1990 to 1994 , resulting in $20 \%$ annual growth of the domestic market.

The Thai government relaxed controls on the automotive industry because the state sensed the necessity to closely follow the trends of technological development in major producing countries, such as Japan and Europe, to reach its internationalization goal. In view of this, it implemented an open industry policy, and chose the development mode of cooperation with foreign investors. The Thai government thus developed a series of measures including reduced tariffs, eight years of corporate income tax exemption, offsetting import taxes on machinery and equipment, material import duty rebates, and further relaxations of trade restrictions.

Table 2: Comparison of Thailand's import tariffs on CBU and CKD (1986-2000)

\begin{tabular}{|c|c|c|c|c|c|c|c|c|}
\hline $\begin{array}{c}\text { Mode } \\
\text { Year }\end{array}$ & \multicolumn{2}{|c|}{$\begin{array}{l}\text { Sedan under } \\
2300 \mathrm{cc}\end{array}$} & \multicolumn{2}{|c|}{$\begin{array}{l}\text { Sedan over } \\
2300 \mathrm{cc}\end{array}$} & \multicolumn{2}{|c|}{$\begin{array}{l}\text { One-ton Pick- } \\
\text { up truck }\end{array}$} & \multicolumn{2}{|c|}{ Big truck } \\
\hline & $\mathrm{CBU}$ & CKD & $\begin{array}{c}\mathrm{U}^{\mathrm{CB}} \\
\end{array}$ & $\begin{array}{l}\text { CK } \\
\mathrm{D}\end{array}$ & CBU & CKD & $\begin{array}{l}\mathrm{CB}^{\mathrm{CB}} \\
\end{array}$ & $\begin{array}{l}\text { CK } \\
\mathrm{D}\end{array}$ \\
\hline 1986 & 180 & 112 & 300 & 112 & 120 & 30 & 40 & 10 \\
\hline 1991 & 60 & 20 & 100 & 20 & 60 & 20 & 40 & 10 \\
\hline 1992 & 42 & 20 & 68.5 & 20 & 60 & 20 & 40 & 10 \\
\hline 1994 & 42 & 20 & 68.5 & 20 & 60 & 20 & 40 & 10 \\
\hline 1997 & 80 & 20 & 80 & 20 & 60 & 20 & 40 & 10 \\
\hline 1999 & 80 & 20 & 80 & 20 & 60 & 20 & 40 & 10 \\
\hline 2000 & 80 & 33 & 80 & 33 & 60 & 33 & 40 & 10 \\
\hline
\end{tabular}

Source: Based on data obtained from the Board of Investment, Thailand, and the Thai Embassy in Japan,

The Period of Embracing Free Trade (2000-now)

The internationalization of Thailand's automotive industry began in the 1990s. After the financial crisis of 1988, Thailand continued an active policy of opening its economy. ${ }^{7}$ To mitigate liquidity problems, it

\footnotetext{
7 The Asian financial crisis of 1997 hit the Thai
}

adopted deregulation to allow foreign investors to own $100 \%$ of their Thai subsidiaries. This policy could solve the overcapacity problem caused by a shrinking

economy and caused great damage to the automotive industry, causing a sharp fall in the domestic and regional market demand, and thus shrinking car production by $40 \%$. 
domestic market by increasing exports. However, it was a response to globalization and the need for greater regional economic integration.

After joining the World Trade Organization (WTO) in 2000, Thailand abolished its rules of origin on vehicle and components, and allowed multinational companies to set up wholly owned enterprises. Consequently, foreign investors dominated the auto assembly industry, while local firms were engaged in the supply chain related to spare parts.

In addition to the WTO norms, regional integration in the ASEAN Free Trade Area (AFTA) accelerated the liberalization of the Thai automotive industry. The AFTA norms lowered import tariffs and non-tariff measures to between $0 \%$ and $5 \%$ in 2003 for old member states of the ASEAN (Brunei, Indonesia, Malaysia, Philippines, Singapore, and Thailand). The automotive industry in Thailand was included in the list of five main industries by the Board of Investment (BOI) that the government used to attract more multinational manufacturers to build plants in Thailand. The ASEAN Industrial Cooperation Scheme (AICO) states that when the auto parts manufacturing industry of a country meets the standard of using parts that are $40 \%$ locally made, it can then enjoy a $0 \%$ to $5 \%$ special tariff within ASEAN. Thailand implemented a liberalization policy and its tariff reduction projects met the time frame and standards set out in this free trade agreement. Therefore, since 2003, Thailand has reduced tariffs on imported cars to $5 \%$ (Hsu, 2002).

The dependent development mode of Thailand's automotive industry led to the following results: its automotive industry ranks as the fifth largest export industry; as a car exporter, Thailand ranks the first among ASEAN countries and the third in Asia after Japan and South Korea; and Thailand made cars are sold in the United Kingdom, Canada, and Australia. Thailand also has the largest automotive assembly base in Southeast Asia, and has become one of the top ten auto manufacturers; it has 16 domestic car assembly plants and 1,800 component production plants; and after 2005, it has produced more pick-up trucks than any other country worldwide (Zhao, 2006).

\section{Thailand's auto industry policy}

In view of Thailand's auto industry policy, the Ministry of Industry has been responsible for its control and adjustment and the secondary Automotive Industry Association has been in charge of setting up specific industrial policies and development plans. The following chart shows the industrial policies implemented from 1962 to 2000 to nurture the Thai automotive industry.

Table 3: Thailand's auto industry policies

\begin{tabular}{|c|c|}
\hline Year & Industrial Policy \\
\hline 1962 & $\begin{array}{l}\text { Implemented an automotive assembly industry-promotion } \\
\text { system (five-year reduction in import tariff on CKD to 50\%, five-year } \\
\text { reduction of corporate tax). }\end{array}$ \\
\hline 1967 & $\begin{array}{l}\text { Increased the import tariff on whole vehicles to } 60 \% \text {; lowered the } \\
\text { import tariff on CKD for sedans by } 30 \% \text {, special trucks } 20 \% \text {, and } \\
\text { trucks } 10 \% \text {. }\end{array}$ \\
\hline 1975 & Implemented $25 \%$ localization. \\
\hline 1978 & Prohibited auto imports, reexamined import tariff rates, and \\
\hline
\end{tabular}




\begin{tabular}{|c|c|}
\hline & rohibited the establishment of car assembly plants. \\
\hline 1980 & $\begin{array}{l}\text { Began domestic car parts design (achieving the goal of } 50 \% \text { in } \\
\text { 1983). }\end{array}$ \\
\hline 1982 & Froze the ratio of automotive localization at $45 \%$. \\
\hline 1983 & $\begin{array}{l}\text { Proposed a new auto industry development policy, the goal of } \\
\text { localization, with sedans at } 54 \% \text { in } 1987 \text {, special trucks at } 62 \% \text { in } \\
\text { 1988, and included the norms for new models, that imported body or } \\
\text { engine parts and gearboxes only have one selection. }\end{array}$ \\
\hline 1985 & $\begin{array}{l}\text { Allowed vehicle importation with over } 2.3 \mathrm{~L} \text { displacement, } \\
\text { although the import tariff was } 300 \% \text {. }\end{array}$ \\
\hline 1986 & Small commercial vehicles must use domestic engines. \\
\hline 1989 & Implemented the use of $20 \%$ domestic engines. \\
\hline 1991 & $\begin{array}{l}\text { Allowed the import of vehicles with under } 2.3 \mathrm{~L} \text { displacement, } \\
\text { reduced import tariff rate for sedans with over } 2.3 \mathrm{~L} \text { displacement } \\
\text { from } 300 \% \text { to } 100 \% \text {, that for under } 2.3 \mathrm{~L} \text { displacement from } 180 \% \text { to } \\
60 \% \text {, for bulk-type sedans from } 112 \% \text { to } 20 \% \text {, and bulk-type trucks } \\
\text { from } 30 \% \text { to } 20 \% \text {. }\end{array}$ \\
\hline 1992 & $\begin{array}{l}\text { Changed import tariffs on whole cars, with sedan under } 2.4 \mathrm{~L} \\
\text { displacement falling from } 60 \% \text { to } 42 \% \text {, sedans with over } 2.4 \mathrm{~L} \\
\text { displacement from } 100 \% \text { to } 68.5 \% \text {, special trucks from } 120 \% \text { to } 60 \% \text {, } \\
\text { including Value-Added Tax and the repeal business tax. }\end{array}$ \\
\hline 1993 & $\begin{array}{l}\text { Abolished the restriction of setting up auto assembly plants, } \\
\text { allowed vehicles less than two years old to be used as taxis. }\end{array}$ \\
\hline 1994 & Implemented preferential tariffs on whole car exports. \\
\hline 1997 & $\begin{array}{l}\text { Abolished a unified price system for vehicles with under } 1.6 \mathrm{~L} \\
\text { displacement; repealed consumption tax on vehicles for less than ten } \\
\text { passengers and priced below } 100 \text { million baht. The Value-Added tax } \\
\text { rate was increased from } 7 \% \text { to } 10 \% \text {, all import tariffs on vehicles } \\
\text { were raised to } 80 \% \text {. Excise tax on sedans and special trucks was } \\
\text { raised to } 5 \% \text {. }\end{array}$ \\
\hline 1998 & $\begin{array}{l}\text { Relaxed the restriction on auto financing payment caps, which } \\
\text { were relaxed from } 48 \text { months to } 72 \text { months, and lowered the down } \\
\text { payment ratio of the total selling price from } 25 \%-30 \% \text { to } 10 \%-20 \% \text {. }\end{array}$ \\
\hline 2000 & Repealed all requirements for auto parts localization. \\
\hline
\end{tabular}

Thailand chose the dependent development mode based on its attitude toward foreign capital. Thailand has adopted an open-door policy since 1885, particularly under the effect of British colonial policy development, and thus the long relationship between Thailand and transnational corporations has been very close. Because of this, the early stage of economic development in Thailand relied on dependency and economic interaction, formed in the context of having a "UK-core" and "Thailand-frontier." Since 1950, the state has acted to gradually improve the position of Thailand in the international economic structure. Therefore, its continued cooperation with foreign investors and multinational corporations has enhanced its domestic industrialization, dependent development has become the key policy for industrialization, and the relationship and interaction between the state and 
multinational corporations has also become more important (Soong, 1996).

In the 1970s, during the early developmental stage of Thailand's automotive industry, high tariffs and restrictions of origin were used to protect the domestic industry, while a limited number of car models were produced to gain the economic benefits of scale. However, these protectionist measures did not lead to the rapid development of the local automotive industry, because high car prices limited domestic demand, which was not conducive to industrial development. After the 1980s, the middle-class had grown considerably in Thailand, the state gradually lost its ability to lead industrial policy, and the government bureaucracy lacked effective tools to undertake this. Therefore, in the developmental mode, opening and renewing cooperation with foreign investors, particularly Japanese multinational corporations, became necessary (Heggard, 1998). Economic growth in the 1990s caused considerable domestic demand for automotive, which forced the government to open the market to car imports and relax restrictions on car models. Hence, the automotive industryinvestment promotion policy in Thailand attracted multinational auto manufacturers to set up plants in the country, expand the scale of the industry, and establish a regional production centre. After the financial crisis in the 1990s, the state turned its industrial policy objectives toward the international market. Because joint ventures produced most of the cars and components, through the market channels and international operating experience of their international cooperation partners, Thai firms acquired the ability to integrate with the international market.

Similar to Malaysia, Thailand attempted to develop a domestic car in the 1980s. However, because high import tariffs resulted in substantial revenues for the state, this plan was cancelled under the pressure of domestic tax units. The evolution of Thailand's automotive industry policy has shown that the State implemented import tariffs and localization as protection measures and set up major development models, limiting car production to assist main products in reaching market size.

\section{Comparison of the development of the automotive industry in Malaysia and Thailand}

\section{Sales, production efficiency, and technology}

Malaysia also began to develop its auto industry in the 1960s; however, the different development mode adopted achieved different results to those in Thailand. In the initial stages of their industries, vehicle production volume and sales in Thailand were both less than those of Malaysia, with the former implementing protectionist policies. However, since the adoption of an open market policy in Thailand in 1990, both its production and volume not only surpassed Malaysia, but also entered the international auto market. In 2000, auto exports in Thailand exceeded sales in the domestic market, and since 2004, approximately one third of all vehicles produced in Thailand have been for export. In contrast, the auto industry in Malaysia has been substantially more limited and with far fewer exports, shown in Table 4. 
Table 4: Comparison of auto production and sales in Malaysia and Thailand

\begin{tabular}{|c|c|c|c|c|}
\hline Year & \multicolumn{2}{|c|}{ Thailand } & \multicolumn{2}{c|}{ Malaysia } \\
\hline & $\begin{array}{c}\text { Homem } \\
\text { ade car } \\
\text { production }\end{array}$ & $\begin{array}{c}\text { Domesti } \\
\text { c sales }\end{array}$ & $\begin{array}{l}\text { Homema } \\
\text { de car } \\
\text { production }\end{array}$ & $\begin{array}{c}\text { Domesti } \\
\text { c sales }\end{array}$ \\
\hline 1985 & 83,105 & 85,222 & 107,030 & 94,999 \\
\hline 1990 & 304,843 & 304,062 & 191,580 & 165,861 \\
\hline 1995 & 525,680 & 571,580 & 288,838 & 285,792 \\
\hline 2000 & 411,721 & 262,189 & 360,105 & 343,173 \\
\hline 2003 & 750,512 & 533,176 & 426,646 & 405,745 \\
\hline 2004 & 928,081 & 625,435 & 471,975 & 487,605 \\
\hline
\end{tabular}

Source: Fuangkajonsak, 2006, p. 24.

Table 5: JAMA manufacturing capacity ratings for Thailand and Malaysia

\begin{tabular}{|c|c|c|}
\hline Item & Thailand & $\begin{array}{c}\text { Malaysi } \\
\text { a }\end{array}$ \\
\hline Engine & High & Low \\
\hline Engine parts & High & Low \\
\hline $\begin{array}{c}\text { Electronic } \\
\text { systems }\end{array}$ & High & Standard \\
\hline Braking system & Standard & High \\
\hline Interior & High & Low \\
\hline
\end{tabular}

Source: Fuangkajonsak, 2006, p. 45

Table 6: Price comparison of the same vehicle in Malaysia and Thailand

\begin{tabular}{|c|c|c|c|}
\hline Model & $\begin{array}{l}\text { Price in } \\
\text { Thailand }\end{array}$ & $\begin{array}{c}\text { Price in } \\
\text { Malaysia }\end{array}$ & Remarks \\
\hline NISSAN X Trail & 120,909 & 136,030 & \multirow{3}{*}{$\begin{array}{c}\text { RM units } \\
\text { calculated on the } \\
\text { Thai baht } 1: 11 \text { (Price } \\
\text { in 2006) }\end{array}$} \\
\hline $\begin{array}{l}\text { TOYOTA Camry } \\
2.0 \mathrm{E}\end{array}$ & 105,000 & 149,149 & \\
\hline HONDA Civic 2.0E & 92,727 & 127,465 & \\
\hline
\end{tabular}

Source: Organized from brand websites in both countries.

At the technical level, research by the Japanese Automotive Manufacturers Association (JAMA), indicates that the auto industry in Malaysia performs worse than

When comparing the same models, the prices of imported cars in Malaysia are more than $10 \%$ higher than in neighbouring countries, shown in Table 6. In contrast, driven by the State and foreign capital,

From an economic point of view, researchers believe that the competitive advantage of the automotive industry in Thailand lies in the following elements: the
Thailand for industrial technology, export capabilities, product cost, manufacturing capacity, and other measures of industrial competitiveness, shown in Table 5.

Thailand has earned the reputation of being the Asian Detroit. Compared with Thailand's "dependent development," Malaysia's "independent development" has led to a lack of industrial competitiveness. investment of foreign capital; emphasis on technology transfer from foreign enterprises, and training local technical staff to build up the industrial development 
base; and support from the State encourages car exports. ${ }^{8}$ In contrast, the literature provides six main reasons for the decline of the Malaysian auto industry: (1) Increased competition in global markets, making it difficult for domestic companies to enter into direct competition with multinational corporations (MNCs) ${ }^{9}$; (2) Increasingly stringent new vehicle standards in the international automotive market, of which most small factories cannot afford the related R\&D costs; (3) A new era of high oil prices, which has reduced Page: 70 consumer demand; (4) A globalization trend, which has led to the concept of a "World Car," of which small regional firms cannot compete with such approaches; (5) Improved economy in Malaysia, resulting in consumer desire to buy foreign cars ${ }^{10}$; and (6) An already saturated domestic market in Malaysia. Although Malaysia has promoted its domestic cars as an export brand, the country's limited market cannot achieve the economies of scale needed to reduce costs. The financial crisis of 1997 shrank the domestic market, and hurt the industrial environment for the development of Malaysia's domestic auto industry (Holland, 2001).

Although Malaysia built up the industrial scale of its automotive industry, and the government continued its intervention and protection, it never considered the issue of industrial selfreliance. State protection caused laziness and complacency in production and

\footnotetext{
8 Jing Liu, "The Development Status and Prospects of Thailand's Automotive Industry," Auto Industry Research, No. 6, 2005, pp. 1-3.

9 International auto plants brought the following production modes and technologies, such as: "Just In Time" (JIT), global logistics, better component supply relationships with upstream and downstream secondary and tertiary level plants, and outsourcing, which depends on a great market size.

10 To date, Proton's production has still not reached economies of scale, and only a limited range of car models is offered.
}

operations, and managers lacked the power to seek cost minimization, which led to low production efficiency. Compared with Malaysia, the Thailand automotive industry courted multinational corporations, which not only brought capital, but also advanced technology and management methods. This is why a more open attitude is considered the main reason for the positive development of Thailand's automotive industry.

\section{Response to free trade}

In addition to technology and sales issues, the bigger challenge for the automotive industry in Southeast Asian countries comes from international pressure related to removing market protection. Besides the World Trade Organization, the cooperation of automotive industries in ASEAN countries, under the concept of economic cooperation, has become a key element in the region's industrial cooperation plan. ASEAN countries thus believe that technical cooperation and trade liberalization can help auto part and vehicle production companies achieve economies of scale, and thus reduce production costs. If the automotive industry in ASEAN countries is unable to cooperate actively to reach greater market size, it will be unable to increase its industrial competitiveness. The cooperation of regional industries can reduce the development costs of shared components, and help expand overseas markets.

However, under economic cooperation, the removal of trade barriers would cause the automotive industry in ASEAN countries to face challenges related to greater international competition, the liberalization of production and sale, and industrial repositioning and efficiency improvement. The auto industry in Malaysia had enjoyed protection in many areas, and was thus adversely affected by ASEAN's cooperation plan, which lowered 
tariffs on vehicle imports and removed the "approved permit" of non-tariff barriers, increasing the pressures related to free trade (Abdullah, 2006). To protect its automotive industry, the Malaysian government has persistently entered it in the list of sectors temporarily excluded from tariffs, and thus delayed tariff reductions from $20 \%$ in 2005 , to $0 \%-5 \%$ in 2008 . The government replaced import tariffs with excise duties, which proved to be a more flexible approach to avoid much of the effects of the ASEAN open market policy and did not consider abolishing import licensing until the end of 2010. These practices all violated the terms of the ASEAN economic cooperation agreement specification, and have been criticized by other member states.

Table 7: ASEAN countries' tariff reduction schedule for imports of fully assembled

cars

\begin{tabular}{|c|c|c|c|c|c|c|c|c|c|}
\hline Country & 2002 & 2003 & 2004 & 2005 & $\begin{array}{r}2 \\
006^{2}\end{array}$ & $\begin{array}{r}2 \\
007\end{array}$ & $\begin{array}{r}2 \\
008 \\
\end{array}$ & $\begin{array}{r}2 \\
009\end{array}$ & $\begin{array}{r}2 \\
010\end{array}$ \\
\hline Thailand & $15 \%$ & $5 \%$ & $\rightarrow$ & $\rightarrow$ & $\rightarrow$ & $\rightarrow$ & $\rightarrow$ & $\rightarrow$ & $0 \%$ \\
\hline Philippines & $20 \%$ & $5 \%$ & $\rightarrow$ & $\rightarrow$ & $\rightarrow$ & $\rightarrow$ & $\rightarrow$ & $\rightarrow$ & $0 \%$ \\
\hline Indonesia & $5 \%$ & $\rightarrow$ & $\rightarrow$ & $\rightarrow$ & $\rightarrow$ & $\rightarrow$ & $\rightarrow$ & $\rightarrow$ & $0 \%$ \\
\hline Malaysia & $\begin{array}{c}\text { No } \\
\text { reduction }\end{array}$ & $\begin{array}{c}\text { No } \\
\text { reduction }\end{array}$ & $\begin{array}{c}\text { No } \\
\text { reduction }\end{array}$ & $15 \%$ & $5 \%$ & $\rightarrow$ & $\rightarrow$ & $\rightarrow$ & $0 \%$ \\
\hline Vietnam & $\begin{array}{l}\text { No } \\
\text { reduction }\end{array}$ & $\begin{array}{l}\text { No } \\
\text { reduction }\end{array}$ & $\begin{array}{l}\text { No } \\
\text { reduction }\end{array}$ & $\begin{array}{l}\text { No } \\
\text { reduction }\end{array}$ & $\begin{array}{l}20 \\
\%\end{array}$ & 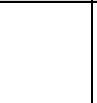 & $20 \%$ & $5 \%$ & \\
\hline
\end{tabular}

Source: ASEAN Automotive Integration: Private Sector Perspective, reference paper in the 8th APEC Automotive Dialogue, Bali, Indonesia, 15-18 May 2006.

In contrast to the situation in Malaysia, the ASEAN Industrial Cooperation (AICO) agreement offers tax incentives to automotive factories in this region, and one of the conditions for receiving this aid is that over $50 \%$ of the products must be exported (Jing, 2001). Thailand has the largest automotive market and production in Southeast Asia, and thus is the biggest potential beneficiary of this policy. Based on the concept of free trade, Thailand also included auto parts as the main tariff reduction item in its free trade agreements with Australia, New Zealand, and India. In addition to having export advantages, the Thai government also announced that, since 2009, for small vehicles worth less than US $\$ 15,300$, the excise tax would fall from $30 \%$ to $17 \%$. The main purpose for this policy was to develop an eco-car model as the country's second industrial development plan, following the successful experience of the plan focused on pick-up trucks. Given these preferential terms, some important international manufacturers chose Thailand as their production base. Thailand also allows transnational automotive groups to fully own their factories, thus reducing the problem of patent violations. The ultimate goal of Thailand's national industrial policy has been to make it the global production center for pick-up trucks and eco-cars (Jian, 2008).

The developmental scholar R. H. Wade (2003), has noted that economic globalization has changed the global industrial environment and forced developing countries to face diverse situations. When the ability to engage in protectionism and state intervention becomes limited, the state must face trade liberalization issues by adopting different 
strategies to obtain further economic development. The threshold for a country's automotive industry to enter the international market is rather high, and when facing the challenges of globalization, Thailand has been more flexible and forward-looking, while Malaysia, due to its protectionist policies and the lack of multinational strategic alliances, has lost the opportunity to enhance competitiveness.

\section{Response and Reflection: the Political Economy of the State and Industrial Policy}

The Choice of Industrial Strategies: "independent development" and "dependence mode" for the automotive industry

The preceding discussion of the different industrial development strategies adopted by Thailand and Malaysia shows that the State played an important role in the automotive industries of both countries, and that both economic development modes are state-led. Both countries hoped to develop an automotive industry with the aid of state intervention, and both achieved rapid establishment of industrial scale, with the goal of industrial internationalization to export their production to other countries.

The main difference between the industrial policies of Thailand and Malaysia is the specific developmental strategy adopted: the former chose the "dependence mode," while the latter, "independent development." While Thailand's dependence mode went through an industrial protection stage involving national intervention, the purpose of this was not to replace, but rather promote, local enterprises and investment. The State then chose to form a relationship of production and technological cooperation with transnational automotive companies. This situation is similar to what Wade mentioned: transnational (automotive) groups that wish to invest in developing countries not only consider the domestic market, but also aim to incorporate the industrial base of developing countries into their global production and supply chains. The automotive industry in Thailand was built on the following basis: the state's "interactional voluntarism" was combined with international and domestic capital to form a "triple-alliance," and this created the mechanisms needed for independent development.

The developmental experience of Thailand's automotive industry demonstrates how the government of developmental states can remain independent and make the industry selfreliant after it has first been established and built up. Scholars of developmental states propose that even though state intervention or protection might cause rent-seeking and laziness, a period of protectionism might benefit industrial development in the long run. When facing pressure from a more open market, and finding that national intervention and other strategies could not prevail, Thailand amended its industrial strategy to one of following the market, and thus was able to continue to maintain industrial competitiveness. This approach is similar to a more recent idea in national development theory, the State-market condominium approach, which does not see the state and the market as opposed to each other.

Professor Wan-Wen Chu noted that although national intervention might help, it will not necessarily promote industrial development. An examination of how different countries developed their automotive industries revealed that South Korea as one of the few successful cases that undertook an independent development strategy. Thus the question must be asked as to why this is so rarely successful. The answer is because the automotive industry in developing countries must rely on the local market to establish the production 
scale. However, the domestic market is limited by the country's economic development, and manufacturers must thus fight in a highly competitive and rather small market. To achieve greater success, most domestic manufacturers choose to introduce transnational capital, technology, and brands. Hence, most automotive manufacturers in developing countries have cooperated with major firms from the U.S. and Japan, and have become part of the global network of large, transnational automotive groups. In contrast to Thailand, after the 1970s, Malaysia developed a more active form of national capitalism based on the New Economic Policy and Economic Nationalism, which considered the automotive industry as a national industry, and one that should follow the mode of independent development. However, the policy of protecting a national brand, in this case Proton, meant that the industry lost the opportunity to integrate with the global market. The small domestic market could not create economies of scale, the state did not change its policy from one of marketleading to following the market, and thus, the Proton project gradually declined. This shows that within the global system structure, it is difficult for industries in developing countries to undertake selfreliant development.

Finally, research in the field of political economics shows that so-called triple alliances, the combination of international and domestic capital, and the State, can be both dynamic and transformative. The external structure (competition among transnational corporations) and the internal structure (national and local business alliances) change over time and allow the fluctuation of forces, which affects the form of such alliances. However, although there may be changes, as the studies of Arrighi and Drangel and Gereffi (1992) have shown, it is rare to maintain their status of a consistent upward or downward structure.
In the world system, $95 \%$ of countries still maintain their original structure. Therefore, even though a triple alliance can be transformative, whether the automotive industry in Thailand can break the structural relationship of the international political and economic system, and move toward complete self-reliance in the industrial development, remains doubtful.

Political nature of the Industry: National political and economic structure and rentseeking

Comparing the economic development strategies of Malaysia and Thailand shows both economic and political differences. For some developing countries, state involvement in industrial policy is based on political considerations, and thus industrial policy is an important tool for implementing nationalism. As mentioned earlier, due to specific factors related to certain domestic groups, the automotive industry in Malaysia was not fully established based on economic considerations, and political factors became an obstacle to its reform.

During development of Malaysia's automotive industry, Prime Minister Mahathir proposed a "domestic car production project" with the aim of promoting the businesses of local Malay groups. Malay firms were thus a beneficiary of this project, from which emerged the new rich class. This consolidated Mahathir's leadership of both the United Malays National Organization (UMNO, Malay group's ruling party) and Barisan Nasional (Malaysia's ruling coalition), and suppressed Chinese-based opposition forces. The state's industrial policy became a vehicle for arbitrary political and economic decision-making in Mahathir's 22year reign.

In brief, the automotive industry became an important means of maintaining sovereignty for the Malay community. This 
is consistent with the criticism of neoclassical economics of state intervention in industry. Further analysis of the Proton ownership structure found that the shareholders were mostly the state or enterprises from the Malay community. This proves that in Malaysia's domestic car protection plan, social outcomes were far more important than profit. Therefore, even though the project was not economically successful, the state continued to support it, and reform was difficult to achieve.

Table 8: Proton ownership structure in 2005

\begin{tabular}{|c|c|c|c|c|}
\hline Ranking & Shareholder & $\begin{array}{c}\text { Number of } \\
\text { shares }\end{array}$ & $\%$ & $\begin{array}{l}\text { Political and } \\
\text { economic } \\
\text { background }\end{array}$ \\
\hline 1 & KHAZANAH NASIONAL BERHAD & $\begin{array}{c}210,484,69 \\
3\end{array}$ & $\begin{array}{c}38.32 \\
\%\end{array}$ & State-controlled \\
\hline 2 & $\begin{array}{c}\text { EMPLOYEES PROVIDENT FUND } \\
\text { BOARD }\end{array}$ & $60,017,000$ & $\begin{array}{c}10.93 \\
\%\end{array}$ & $\begin{array}{l}\text { Government } \\
\text { controlled fund }\end{array}$ \\
\hline 3 & $\begin{array}{l}\text { RHB NOMINEES (TEMPATAN) SDN. } \\
\text { BHD. } \\
\text { PERTROLIAM NASIONAL BERHAD }\end{array}$ & $35,676,680$ & $6.50 \%$ & $\begin{array}{l}\text { National } \\
\text { Petroleum } \\
\text { Holdings }\end{array}$ \\
\hline 4 & $\begin{array}{l}\text { CIMSEC NOMINEES (TEMPATAN) } \\
\text { SDN. BHD. } \\
\text { SECURITY TRUSTEE (KCW ISSUE 2) }\end{array}$ & $24,250,000$ & $4.42 \%$ & $\begin{array}{c}\text { Indigenous } \\
\text { government-led } \\
\text { investment bank }\end{array}$ \\
\hline 5 & LEMBAGA TABUNG HAJI & $16,820,427$ & $3.06 \%$ & $\begin{array}{l}\text { Islamic funds, } \\
\text { based on a vast } \\
\text { rubber plantation }\end{array}$ \\
\hline 6 & $\begin{array}{l}\text { CARTABAN NOMINEES (ASING) } \\
\text { SDN. BHD. GOVERNMENT OF } \\
\text { SINGAPORE INVESTMENT } \\
\text { CORPORATION PTE.LTD. FOR } \\
\text { GOVERMENT OF SINGAPORE (C) }\end{array}$ & $14,185,300$ & $2.58 \%$ & $\begin{array}{l}\text { Singapore's state- } \\
\text { controlled fund } \\
\text { (foreign capital) }\end{array}$ \\
\hline 7 & PERMODALAN NASIONAL BERHAD & $8,838,000$ & $1.61 \%$ & $\begin{array}{l}\text { Indigenous } \\
\text { Education } \\
\text { Development } \\
\text { Fund }\end{array}$ \\
\hline 8 & $\begin{array}{c}\text { CARTABAN NOMINEES } \\
\text { (TEMPATAN) SDN. BHD. AMANAH } \\
\text { SSCM NOMINEES (TEMPATAN) SDN. } \\
\text { BHD. FOR EMPLOYEES PROVIDENT } \\
\text { FUND BOARD (JF404) }\end{array}$ & $8,094,900$ & $1.47 \%$ & $\begin{array}{l}\text { Malaysia } \\
\text { Employment } \\
\text { Fund }\end{array}$ \\
\hline 9 & PERECOM INDUSTRIES SDN. BHD. & $7,444,000$ & $1.36 \%$ & $\begin{array}{c}\text { Malaysia } \\
\text { Technology } \\
\text { Group }\end{array}$ \\
\hline 10 & $\begin{array}{l}\text { HSBC NOMINEES (ASING) SDN. } \\
\text { BHD. TNTC FOR SAUDI ARABIAN } \\
\text { MONETARY AGENCY }\end{array}$ & $6,835,998$ & $1.24 \%$ & $\begin{array}{l}\text { HSBC, Foreign } \\
\text { Capital }\end{array}$ \\
\hline
\end{tabular}

Source: Proton Holdings Berhad, Annual Report 2006. 
As for the protection of the automotive industry, in addition to state regulation of the ownership structure and industrial supply chain, the Malaysian policy that was most criticized by other ASEAN countries was the use of Approved Permits (AP) to protect domestic assembly plants, and offer more opportunities for Malay enterprises to participate in the sales of imported cars. As the country's economy developed, the demand for imported cars also increased, and those who had an AP could control import quotas, leading to political competition. Malaysia's industrial policy eventually evolved into chips-distributing political favouritism, which weakened the competitiveness of external competitors (foreign car manufacturers) when they tried to enter the domestic market.

In contrast to Malaysia, by following economic development policies and open politics, public and private sectors in Thailand have transformed from a relationship of "Clientism" to "Partnership" since the 1980s. The industrial sector improved the effect of state policy, and industrial policy accordingly adjusted to regime change. Before the 1980s, Thailand had an authoritarian military regime, and preferred the policies of state capitalism and economic nationalism. After the 1980s, Thailand adopted the industrial policy of a self-adjusting market, and supervision from public opinion and interest groups helped the automotive industry make adjustments in the direction of market liberalization and transformation (Shen, 2004).

Differing from Thailand's frequent coups and lack of effective state intervention, Malaysia has a strong state and the ethnic Malay community has continued to dominate the political system, and lead the industrial policy formulated by the State. The automotive industry appears to have adopted "rent-seeking" behavior, the political effect of market intervention, with political factors being the major obstacles to industry transformation. Because of the political and economic structure, the State (controlled by ethnic Malay communities), domestic capital (controlled by Chinese enterprises), and foreign capital could not build a cooperative relationship and was not able to follow Thailand's dependency development example and form a triple alliance. The country's economic policy and heavy industry policy have deterred Chinese capital from investing in the automotive industry, and thus impeded the capital investment required for industrial transformation (Lubeck, 1992). When noneconomic goals became more important than economic ones, the lack of an adjustment to Malaysia's development strategy in the face of the challenge of opening up to international markets eventually leads to significant problems with industrial development.

\section{Conclusion}

Comparing the automotive industries in two newly industrialized Southeast Asian countries, Malaysia and Thailand, this research examines how, during the process of economic development, the State chose to intervene in industrial development, and how it influenced the political and economic situation. As in many other developing countries, Malaysia has a strong state and was able to use the New Economic Plan and the National Plan of Heavy Industry as policy tools to establish a domestic industry. Establishment of the automotive industry in Malaysia was thus the result of protectionist policies based on political and economic reasons, consistent with the ideology of "indigenous priority."

Differing from Malaysia, the early automotive industry in Thailand also chose 
to employ market protection, and use import-substitution as the developmental strategy. This research found two significant differences between Malaysia and Thailand in how the State conducted its industrial policy. First, two different industrial strategies were chosen, namely independent development in Malaysia and dependency development in Thailand. Second, the political nature of the Malaysia automotive industry hindered its subsequent industrial policy, and made it difficult to adopt a policy of following the market. In short, industrial development, particularly the automotive industry, has been closely related to Malaysian political and economic characteristics.

In contrast, as the Thai government stated in its "Automotive Industry in Thailand," the country was able to have the largest car assembly market among ASEAN countries and produce the highest quality vehicles because it opened its domestic market and attempted global integration. The country has also had greater potential for market growth and a stable political climate, and a state that supports free trade and open investment policies. Thailand possesses no ethnic conflict or national car program. With a more open attitude, Thailand has attracted more investments into its automotive industry. However, the lack of ethnic problems does not necessarily mean that there is no political interference in the industry, while the lack of a national car program and greater liberalization do not necessarily mean that rent-seeking is not a problem.

Table 9: Political and economic comparison of different developmental strategies used in Malaysia and Thailand

\begin{tabular}{|c|c|c|}
\hline Criteria & $\begin{array}{c}\text { Automotive industry in } \\
\text { Malaysia } \\
\text { Independent Mode }\end{array}$ & $\begin{array}{l}\text { Automotive industry in } \\
\text { Thailand } \\
\text { Dependency Development }\end{array}$ \\
\hline $\begin{array}{l}\text { Key important dates in the } \\
\text { development of the of } \\
\text { industry }\end{array}$ & $\begin{array}{l}\text { - In 1962, the domestic } \\
\text { automotive industry } \\
\text { was first established } \\
\text { - In 1982, the domestic } \\
\text { car production project } \\
\text { was implemented. } \\
\text { - In 1985, the first } \\
\text { domestic car was } \\
\text { introduced, to become } \\
\text { the only domestic car } \\
\text { brand in Southeast Asia }\end{array}$ & $\begin{array}{l}\text { - In 1961, Thailand's } \\
\text { Automotive Industry } \\
\text { Corporation was } \\
\text { established } \\
\text { - In 1980, the import } \\
\text { substitution industrial } \\
\text { policy was implemented } \\
\text { - In 1985, cooperation with } \\
\text { Japanese capital } \\
\text { gradually relaxed } \\
\text { industrial restrictions } \\
\text { - After the 1990s, } \\
\text { industrial policy was } \\
\text { revised to become more } \\
\text { export-oriented }\end{array}$ \\
\hline The Role of the State & $\begin{array}{l}\text { A strong state } \\
\text { dominated industrial } \\
\text { policy and considered } \\
\text { the automotive } \\
\text { industry as a national }\end{array}$ & $\begin{array}{l}\text { - Industrial policy changed } \\
\text { because of political } \\
\text { changes } \\
\text { - After the 1980s, politics } \\
\text { became open and the }\end{array}$ \\
\hline
\end{tabular}




\begin{tabular}{|c|c|c|}
\hline & $\begin{array}{l}\text { industry. Domestic car } \\
\text { manufacturers were } \\
\text { protected by this } \\
\text { policy. } \\
\text { - The political regime } \\
\text { remained unchanged, } \\
\text { and no major revisions } \\
\text { to the industrial policy } \\
\text { were made }\end{array}$ & $\begin{array}{l}\text { State adjusted the } \\
\text { industrial policy }\end{array}$ \\
\hline $\begin{array}{l}\text { With or without national } \\
\text { brand and specific models }\end{array}$ & $\begin{array}{ll}\text { - } & \text { Yes } \\
\text { - } & \text { Proton and Perodua }\end{array}$ & 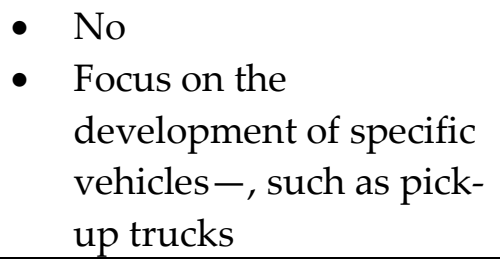 \\
\hline $\begin{array}{l}\text { The relationship between } \\
\text { the industry and politics }\end{array}$ & $\begin{array}{l}\text { - The automotive } \\
\text { industry protected the } \\
\text { distribution and } \\
\text { employment } \\
\text { opportunities of ethnic } \\
\text { Malay individuals, and } \\
\text { placed restrictions on } \\
\text { other ethnic groups. } \\
\text { - Import licenses became } \\
\text { the privilege of Malay } \\
\text { individuals } \\
\text { The industry relied on } \\
\text { the State and was not } \\
\text { market-oriented }\end{array}$ & $\begin{array}{l}\text { - Industrial policy was } \\
\text { more independent of } \\
\text { political influence }\end{array}$ \\
\hline $\begin{array}{l}\text { The relationship with } \\
\text { international car } \\
\text { manufacturers } \\
\text { (multinational enterprises) }\end{array}$ & $\begin{array}{l}\text { The New Economic } \\
\text { Policy and Heavy } \\
\text { Industry Policy } \\
\text { deterred domestic } \\
\text { Chinese investors from } \\
\text { entering the } \\
\text { automotive industry } \\
\text { - Limited cooperation in } \\
\text { the international } \\
\text { market, and the State } \\
\text { dominated industry } \\
\text { development }\end{array}$ & $\begin{array}{l}\text { - State, domestic, and } \\
\text { foreign capital formed a } \\
\text { triple alliance } \\
\text { - Cooperated with } \\
\text { multinational enterprises } \\
\text { and employed industrial } \\
\text { division of labour }\end{array}$ \\
\hline Sales market & $\begin{array}{l}\text { A high proportion of } \\
\text { domestic sales, and } \\
\text { thus the problem of a } \\
\text { saturated domestic } \\
\text { market }\end{array}$ & $\begin{array}{l}\text { A high proportion of } \\
\text { exports, up to one third } \\
\text { of production }\end{array}$ \\
\hline The attitude toward & - Implemented tariff & - Tariff reduction since \\
\hline
\end{tabular}




\begin{tabular}{|l|l|l|}
\hline $\begin{array}{l}\text { ASEAN Industrial } \\
\text { Cooperation and Free } \\
\text { Trade agreements }\end{array}$ & $\begin{array}{l}\text { protection until 2008 } \\
\text { Non-tariff protection of } \\
\text { import licenses was } \\
\text { continued until 2010 }\end{array}$ & $\begin{array}{l}2000 \\
\text { Support for industrial } \\
\text { cooperation and free } \\
\text { trade }\end{array}$ \\
\hline
\end{tabular}

Source: Organized by the author

Jenkin (1995) compared the automotive industry in Taiwan and South Korea and believed that the reason why the latter could build up an independent automotive industry was because the State could overcome pressure from the private sector and multinational companies and gain control of the industry. In contrast, the State in Taiwan could not handle the conflict arising from integration of the domestic private sector and multinational companies, and it became difficult for the government to lead the industry, and thus it lost the opportunity to establish an independent automotive industry. In short, the reasons for the success of South Korea's automotive industry are as follows: a strong state, highly distorted market mechanisms, and the cooperation with a large consortia.

However, this research finds that the opposite situation holds in the countries examined. Specifically, although Malaysia has a strong state, the projects conducted by state-led enterprises have not helped industrial development, while Thailand, which followed an open market model, allowed multinational auto groups to enter the domestic market, which resulted in good industrial development. Why are the results between this study and the earlier one so different? Jomo stated that the developmental modes of newly industrialized countries in East Asia and Southeast Asia differ. However, is this related to a country's relative position in the structure of the global system? This remains a question for future Southeast Asian political and economic research.
Returning to the first discussion about the relationship between the State and the global automotive industry, as global and regional supply chains were formed, the automotive industry in developing countries was increasingly affected by free trade agreements, and it became necessary for them to choose between the strategies of dependency development and the independent mode. Intel's former CEO, Andrew Grove, in his letter to the Wall Street Journal stated: "What can Detroit learn from Silicon Valley?" In the letter, he stated that when one of a country's industries encounters difficulties, they must figure out whether it is because of a fall in competitiveness, or global industrial restructuring. If the former, then national intervention would prove helpful, while it would prove harmful in the latter condition, and even eventually cause the whole nation to lose its competitiveness (Grove, 2009). Grove further stated that the future of the automotive industry, just as the division of labor in the technology industry, is undergoing an ongoing restructuring from a vertical to horizontal mode. Therefore, future vehicles would thus be produced by the assembly of standardized components. In this context, although many Asian manufacturers might not be able to produce a whole car, the ability to control key components would gain them future industry opportunities in these countries. Grove's point of view could serve as the answer to these questions, that is, the state could follow the market and find a new business model and new competitive advantage, all of which are important 
strategies to maintain national industrial development.

\section{About Author}

Dr. Wan-Ping Tai（戴萬平） is currently an associate professor and director at the Department of International Business the Cheng Shiu University, Kaohsiung.

Samuel C Y KU is Professor at the Institute of China and Asia-Pacific Studies, National Sun Yat-sen University, Kaohsiung, Taiwan.

\section{References:}

Geoffrey, R., D. Underhill and Xiaoke Zhan, 2005. "The State-Market Condominium Approach,"in Richard Boyd \& Tak Wing Ngo (eds.), Asian States: Beyond the Developmental Perspective. London: Rutledge.

Abbott, J., 2003. Developmentalism and Dependency in Southeast Asia: the Case of the Automotive Industry. New York: Taylor \& Francis.

Abdullah, Rashid, 2006/12/13-15. "Business Response to the Regional Demands and Opportunity: A Study of Malaysian Automotive industry," paper presented at the Global Issues and Challenges in Business and Economics Conference organized by the Department of Management and Marketing at Corus Paradise Resort, Port Dickson.

Abdulsomad, 2003. "Building Technological Capabilities of Local Auto Parts Firms Under Contrasting Industrial Policies: A Comparative Study of Malaysia and Thailand 1960-2000," in K. S. Jomo, Greg Felker, and Rajah Rasiah (eds.), Industrial Technology Development In Malaysia. London: Almqvist \& Wiksell Internat.

Ahmad, Z. H. and S. M. Alatas, 2005.
"Malaysia: In an Uncertain Mode," in James W. Morely (ed.) Driven by Growth: Political Change in the Asia-Pacific Region. Singapore: Studies of the East Asian Institute.

Amsden, Alice and Wan-Wen Chu, 2003. Beyond Late Development: Taiwan's Upgrading Policies. Cambridge: MIT Press.

Amsden, Alice, 1989. Asia's Next Giant: South Korea and Late Industrialization. NY: Oxford University Press.

Audet, D. and C. Van Grasstek, 1997. "Market Access Issues in the Automotive Sector," in OECD, Organization for Economic Cooperation and Development, Market Access Issues in the Automotive Sector. Paris: OECD.

Automotive Federation of Malaysia (AFM), 1984. "Submission of AFM on the Industrial Master Plan," in The ASEAN Motor Industry in Economist Intelligence Unit. KL: EIU.

Balassa, Bela, 1982. Development Strategies in Semi-industrial Economics. Baltimore: Johns Hopkins University press.

Bhagwati, Jagdish N., 1988. “ExportPromoting Trade Strategy: Issues and Evidence," World Bank Research Observer, Vol. 3, No. 1, 1988, pp. 27-57.

Buchanan, J. M., 1980. "Rent Seeking and Profit Seeking" in J. M. Buchanan, R. D. Tollison and G. Tullock (eds.), Toward a Theory of the Rent-Seeking Society. College Station, Texas A\&M University Press.

Camilleri, J., 2000. States, Markets, and Civil Society in Asia Pacific. New York: Edward Elgar.

China Auto News, 2002/5/6. What kind of automotive industry is it in Malaysia? China Auto News.

Chu, Wan-Wen, 1997. "Demonstration Effects and Industrial Policy: The Birth of Taiwan's Petrochemical Industry," Taiwan: A Radical Quarterly in Social Studies, No. 27, pp.97-138.

Chu, Wan-wen, 2001. "The Effects of Taiwan's Industrial Policy: A Preliminary Evaluation," Taiwan: A Radical Quarterly in Social Studies, No. 42, pp. 67-117. 
Chu, Yun-han, 2008. "American political elites re-embrace Government," Business Weekly, No. 1080, p. 20.

Crouch, H., 1993. "Malaysia: Neither Authoritarian nor Democratic" in K. Hewison, R. Robison and G. Rodan (eds.), Southeast Asia in the 1990's: Authoritarianism ,Democracy and Capitalism. St. Leonards: Allen and Unwin.

Dicken, P., 1998. Global Shift: Transforming the World Economy. London: Paul Chapman Publishing Ltd.

Doner, Richard F., 1991. Driving a Bargain: Automotive Industrialization and Japanese Firms in Southeast Asia. Berkeley: University of California Press.

Ee, Tan Liok, 1992. "Dongjiaozong and the Challenge to Cultural Hegemony," in Joel S. Kahn and Francis Loh Kok Wah (eds.), Fragmented Vision: Culture and Politics in Contemporary Malaysia. Australia: Allen and Unwin.

Evans, P., 1979. Dependent Development: The Alliance of Multinational, State, and Local Capital in Brazil. New York: Princeton University Press.

Fishlow, A., 1994. Miracle or Design? Lesson from the East Asian Experience. Washington D. C.: Overseas Development Council.

Freeman, J. R.,1982. "State Entrepreneurship and Dependence Development," American Journal of Political Science, Vol. 26, No. 1, pp. 90-112.

Fuangkajonsak, W., 2006. Industrial Policy Options for Developing Countries: the Case of the Automotive Sector in Thailand $\mathcal{E}$ Malaysia, Tufts University, Master of Arts in Law and Diplomacy Thesis.

Fujita, M., 1998. "Industrial Policies and Trade Liberalization: The Automotive Industry in Thailand and Malaysia," in Keiji Omura (ed.), The Deepening Economic Interndependence in the APEC Region, APEC Study Center, Institute of Developing Economies.

Gereffi, Gary and Donald L. Wyman,
1990. "Industrial Policy in East Asia: Does it Lead or Follow the Market?" in Gary Gereffi and Donald L. Wyman (eds.), Manufacturing Miracles: Path of Industrialization in Latin American and East Asia. New Jersey: Princeton Press.

Gereffi, Gary, 1992. “Global commodity chains and footwear exports of semiperiphery (Chinese edition)," Thought and Words: Journal of the Humanities and Social Science, Vol. 30, No. 3, pp. 107-139.

Grove, Andrew S., 2009. "What Detroit Can Learn From Silicon Valley: Vertically integrated production is a thing of the past. Will the auto industry's new overseers catch on?" The Wall Street Journal, p. A13.

Gustafsson, F., 2006. The Greasy Palm: Malaysian Industrial Policy and the Palm Oil Industry, Master Thesis, Lund University, Sweden.

Hasan, P., 1976. Korea: Problems and Issues in a Rapidly Growing Economy. Baltimore: The Johns Hopkins University Press.

Heggard, S. M., 1998. "Business, Politics and Policy in East and Southeast Asia," in Henry S. Rowen (ed.), Behind East Asian Growth: The Political and Social Foundations of Prosperity. London: Taylor \& Francis.

Hewison, Kevin, 1988. "The State and Capitalist Development in Thailand," in John G. Taylor and Andrew Turton (eds.), Sociology of Development Societies: Southeast Asia. London: Macmillan.

Holland, Lorien, 2001. "Proton's Positive Spin," Far Eastern Economic Review, No. 164, pp. 55-56.

Hsu, Fu-Tim, 2002. "The effects of the East Asian financial crisis on the development of the ASEAN Free Trade Area," Investment in Southeast Asia (bimonthly), No. 10, 2002, pp. 3-4.

Humphrey, J., 2000. "AssemblerSupplier Relations in the Auto Industry: Globalization and National Development," Competition \& Change, No. 4, pp. 245-271.

Jenkins, Rhys, 1987. Transnational 
Corporations and Uneven DevelopmentDevelopment \& Underdevelopment. London: Rutledge.

Jenkins, Rhys, 1995. "The Political economy of industrial policy: Automotive Manufacture in the Newly Industrializing Countries," Cambridge Journal Economics, No. 15, pp. 625-645.

Jian, Ai-Qun, 2008. "Thailand's auto market overview," in ITIS. http://www.itis.org.tw/rptDetail.screen?rpti $\mathrm{dno}=442296803$.

Jing, Xin-Ci, 2001. "ASEAN Industrial Cooperation and Development," Major National Industrial Economic Policy Quarterly, No. 1, 2001, p. 14-16.

Johnson, C., 1982. MITI and the Japanese Miracle. Stanford: Stanford University Press.

Jomo K. S., 2002/3/15. “State and Market in Economic Development: Southeast Asian Industrial Policy in Comparative East Asian Perspective," paper present at Asia-Latin America Cooperation-ALAC an ECLACUN, IDE/JETRO-Japan and IE/UFRJ-Brazil initiative.

Jomo, K. S., 1994. "Rethinking the Role of Government Policy in Southeast Asia," in Joseph E. Stiglitz and Shahid Yusuf (eds.), The East Asian Miracle: Economic Growth and public Policy - A World Bank Policy Research Report. New York: Oxford University Press, pp.461-508.

Kesavatana, W., 1989. Political Economy of Direct Foreign Investment in Thailand: A Case Study of the Automotive industry, Ph.D. diss., University of Michigan.

Khoo, B. T., 1995. The Paradoxes of Mahathirism. New York: Oxford University Press, 1995.

Konosuke, O., 1993. The Motor vehicle industry in Asia: A Study of Firms and States in Modern Capitalism. Singapore: Asian Manpower Studies by Singapore University.

Kruegert, Anne O., 1993. The Political Economy of Public Policy Reform in Developing Countries. Cambridge, MA: MIT Press.

$\mathrm{Ku}$, Samuel C.Y., 1995. Government and
Politics in Southeast Asia. Taipei: Wunan.

Kuckiki, Akifumi, 2007. "Industrial Policy in Asia," Japan IDE Discussion Paper, No. 128.

Kumon, Shumpei and Henry Rosovsky, 1972. The Political Economy of Japan: Cultural and Social Dynamics. Stanford, California: Stanford University Press.

Lindauder, David L. and M. Roemer, 1994. Development in Asia and Africa: Legacies and Opportunities. New York: ICE Press.

Liu, Jing, 2005. "The Development Status and Prospects of Thailand's Automotive Industry," Auto Industry Research, No. 6, pp.1-3.

Lubeck, Paul M., 1992. "Malaysia Industrialization, Ethnic Divisions, and the NIC Model: the Limits to Replication," in Appelbaum and Henderson, In States and Deployment in the Asian Pacific Rim. London: Sage.

Machado, K. G., 1989. “Japanese Transnational Corporations in Malaysia's State Sponsored Heavy Industrialization Drive: The HICOM Automotive and Steel Projects," Pacific Affairs, Vol. 62, No. 4, p. 504-531.

Nenham, Lim, 2006/5/15-18. “ASEAN Automotive Integration- Private Sector Perspective," paper presented at The $8^{\text {th }}$ APEC Automotive Dialogue, Bali Indonesia.

Office of Industrial Economics, 2006. Automotive Industry in Thailand. Bangkok: Office of Industrial Economics.

Proton Holdings Berhad, 2007. Annual Report 2006. KL: Proton Holdings.

Rasiah, R. and I. Shari, 2001. "Market, Government and Malaysia's New Economic Policy," Cambridge Journal of Economics, Vol. 25, No. 1, 2001, pp. 57-78.

Rasiah, R., 1999. Liberalization and the automotive industry in Southeast Asia, Occasional Paper \#99, Department of Intercultural Communication and Management, Copenhagen Business School.

Rasiah, R., 2001. "Market, Government and Malaysia's New Economic Policy," 
Cambridge Journal of Economics, No. 25, pp. 57-78.

Shen, Yo-Zhong, 2004. "Book Review: Beyond Late Development: Taiwan's industrial upgrading strategy", Political Science Quarterly Book Review, pp. 1-4.

Sin Chew Daily, "2005 Top 10 list of AP holders," http://www.sinchewi.com/special/aplist/index.phtml?sec=723\&a rtid=200507190274.

Soong, Jenn-Jaw, 1996. The Economic Political Development of ASEAN countries. Taipei: Wunan.

Stiglitz, Joseph E. and Shahid Yusuf (eds.), 1994. The East Asian Miracle: Economic Growth and public Policy - A World Bank Policy Research Report. New York: Oxford University Press.

Torii, T., 1991. "Changing the Manufacturing Sector, Reorganizing Automotive Assemblers, and Developing the Auto Component Industry under the New Economic Policy," The Developing Economies, No. XXIX, pp. 387-413.

Wad, P., 1999. Business relations in crisis? The case of the national auto manufacturers in South Korea and Malaysia during the East Asian crisis: Part III: The Malaysian auto industrial networks in a netholder perspective.
Copenhagen: Copenhagen Business School.

Wad, P., 2001. Transforming Industrial Relations: the Case of the Malaysian Auto Industry, IIAS/IISGCLARA Working Paper, No. 12, Amsterdam.

Wade, R. H., 2003. "What Strategies Are Viable for Developing Countries Today? The World Trade Organization and the Shrinking of Development Space," Review of International Political Economy, Vol. 10, No. 4, pp. 621-644.

Wah, Tan Kock and K. S. Jomo, 1995. "Economic Theory and Industrial Policy in East Asia" in Robert Fitzgerald (ed.), The State and Economic Development-Lessons from Far East. London: Frank Cass.

White, G., 1988. Developmental States in East Asia. London: Macmillan.

Zhao, Meng-Yi, 2006. "Taiwan Investment Industry Analysis Report-Thai auto parts industry," in ITIS. http://www.itis.org.tw/pubinfodetail.screen?industry $=4 \& c t g y=15 \&$ pubid $=4$ 1501527.

Zysman, John and Eileen Doherty, 1995. The Evolving Role of the State in Asian Industrialization, BRIE Work Paper 84 . 